\title{
EGALITARIANISME FIQH MU'AMALAH DALAM SISTEM EKONOMI ISLAM
}

\author{
Moh. Asra Maksum \\ IAI Ibrahimy, Komp. Masjid Ibrahimy No. 1-2 Situbondo, \\ mohammadasra64@gmail.com
}

\begin{abstract}
This paper tries to explore the fact that transaction constitutes the most important aspect of Islamic jurisprudence, commonly called fiqh. The paper tries to deal with this aspect in terms of the legal thought of Islam and relates it with the modern concept of egalitarianism. It argues that although egalitarianism becomes the most important value in the legal thought of Islam-as it is clear in the concept of transaction - the tension toward establishing this value has not been easy. This paper hence, does not deal merely with the normative aspect of the value, but also the history behind its establishment. In a way, the paper understands that both the concept of transaction in Islamic legal thought and the concept of egalitarianism share common grounds in that both are about equality, justice, right and obligation. Equality is strongly upheld in Islamic legal thoughts so much so that it is considered as the most driving legal concept in Islamic economics. Hence, the paper partly argues that the characteristic of Islamic economics is equality, nothing else.
\end{abstract}

Keywords: Justice, equality, egalitarianism, sharîa $a$.

\section{Pendahuluan}

Fiqh bidang mu'âmalah merupakan unsur terpenting dalam segmen pemikiran hukum Islam karena ia langsung bersentuhan dengan pranata sosial. Secara normatif, fiqh mu'âmalah dibangun melalui prinsip persamaan, keadilan, pemenuhan hak dan kewajiban. Ragam prinsip tersebut semestinya diapresiasi demi mengefektifkan sistem ekonomi Islam yang memadukan kebebasan dan pertanggungjawaban. Dalam praktiknya, prinsip-prinsip tersebut perlu diaktualisasikan dalam semangat perubahan dan perkembangan peradaban manusia. Sebagai makhluk sosial, manusia selalu berinteraksi dengan lingkungan sekitarnya. Dengan begitu, diperlukan seperangkat aturan 
fiqh mu'âmalab yang dapat mewadahi persoalan-persoalan transaksional sesuai prinsip kesetaraan dan kemaslahatan. Untuk keperluan ini, teori-teori fiqh klasik perlu diaktualisir sesuai realitas dan kebutuhan manusia.

Artikel ini ingin mengulas prinsip egaliter dalam nuansa fiqh mu'ámalab dengan mengacu kepada prinsip-prinsip ideal yang dikonstruksi dari standar normatif teks-teks keagamaan. Harapannya, bahwa prinsip-prinsip tersebut dapat menjadi tolok ukur pemahaman dan penerimaan hukum Islam secara keseluruhan.

\section{Islam sebagai Agama Universal}

Pada dasarnya, Islam diturunkan ke dunia ditahbiskan sebagai rahmat bagi semesta alam ${ }^{1}$ sebagaimana juga ketika Allah menunjuk manusia menjadi khalifah di dunia ini ${ }^{2}$ dalam rangka merealisasikan kemakmuran dan kesejahteraan kehidupan di dalamnya. ${ }^{3}$ Manusia mempunyai tugas pengabdian dalam skala yang luas, ${ }^{4}$ karena pada hakikatnya, aktivitas manusia yang beriman masuk ke dalam terma pengabdian sepanjang keikhlasan tersemat di dalamnya. ${ }^{5}$ Jadi, semua usaha manusia dalam rangka memakmurkan bumi dan seluruh isinya merupakan bentuk pengakuan kepada Allah. Di situlah, Islam sebagai agama yang terkonstruk sebagai sebuah sistem ajaran yang universal.

Untuk mencapai tujuan yang sangat mulia ini, Allah telah memberikan petunjuk yang mencakup segala sesuatu yang dibutuhkan oleh manusia sebagai khalifah Allah di bumi ini, baik petunjuk itu

1 al-Qur'ân, 17: 107.

2 Dalam surah al-Baqarah ayat 30 Allah mengisahkan tentang kelebihan manusia (sebagai makhluk) dibandingkan dengan makhluk lainnya, manusia memiliki kemampuan untuk mengelolah alam, sehingga dia dipercaya dan ditunjuk untuk menjadi khalifah di bumi ini. Lihat al-Qur'ân, 2: 30. Baca lebih lengkapnya dalam Maḥmûd Muhammad Hijâzî, Al-Tafsîr al-Wâdịh, Vol. 1 (Beirut: Dâr al-Jabal, t.th.), 29.

3 al-Qur'ân, 6: 165.

${ }^{4}$ al-Qur'ân, 26: 56.

5 Dalam surah al-Bayyinah ayat 5 Allah berfirman yang artinya: Melaksanakan perintah Allah (baik dalam terma ḥabl min al-Allâh maupun habl min al-nâs) dalam konteks ini, atau dalam artinya yang lain yaitu amal salih yang berbentuk ibadah semata atau amal sebagai wujud kepedulian sosial, salat misalnya sebagai bentuk ibadah ragawi dan zakat sebagai bentuk kesalihan sosial ini, semuanya harus diniatkan sebagai pengabdian kepada Sang Pencipta, bahkan mayoritas ulama berpendapat, bahwa amal perbuatan, merupakan indikator dari iman seseorang. Lihat al-Qur'ân, 98: 5. Baca eksplorasi lebih mendalam Ibn Kathîr, Tafsîr al-Qur'ân al-'Ažîm, Vol. 4 (Beirut: Dâr al-Fikr, t.th.), 574. 
berupa aqidah, akhlak maupun sharî‘ah. Dua komponen pertama, aqidah dan akhlak, bersifat konstan dan absolut. Keduanya tidak dapat direduksi dalam lintasan waktu dan tempat (akan selalu relevan dalam setiap waktu dan tempat). ${ }^{6}$ Sedangkan dalam aspek sharî́ah atau mu'amalah, ia akan senantiasa mengalami perubahan sesuai dengan kebutuhan dan taraf peradaban manusia. ${ }^{7}$ Allah dalam surah al-Nisâ' ayat 5 menegaskan bahwa untuk tiap-tiap umat di antara kamu, Kami berikan aturan dan jalan yang terang. Sekiranya Allah menghendaki, niscaya kamu dijadikan-Nya satu umat (saja), tetapi Allah hendak menguji kamu terhadap pemberian-Nya kepadamu, maka berlomba-lombalah berbuat kebajikan. Hanya kepada Allah-lah kembali kamu semuanya, lalu diberitahukan-Nya kepadamu apa yang telah kamu perselisihkan itu.

Menurut penulis, ayat tersebut di atas menunjukkan adanya nilai fleksibelitas dan elastisitas. Artinya Islam tidak rigid dan eksklusif, karena pernyataan itu dapat diberlakukan kapan dan di mana pun sesuai dengan taraf dan perkembangan peradaban manusia. Oleh karena itu, sharî‘ ah Islam sebagai suatu aturan yang dibawa oleh Nabi Muhammad memiliki keunikan tersendiri. Sebab sharî‘ah ini bukan saja komprehensif tetapi juga universal. Karakter istimewa ini diperlukan, sebab tidak akan ada sharî́ah yang datang kemudian untuk menyempurnakannya.

Komprehensif, berarti sharî'ah Islam mencakup seluruh aspek kehidupan, baik ibadah (ḥabl min Allâh) maupun mu'âmalab (ḥabl min alnâs). Ibadah diperlukan dalam kehidupan beragama untuk menjaga ketaatan dan keharmonisan hubungan manusia dengan Khaliknya. ${ }^{8}$ Sedangkan aspek mu'âmalah merupakan aturan main dalam kehidupan sosial kemasyarakatan sehingga aturannya bersifat longgar sesuai tingkat perkembangan masyarakat.

Sedangkan yang dimaksud dengan universal, bahwa sharî‘ah Islam dapat diaplikasikan di setiap waktu dan tempat (sâlị̣ li kull zamân wa

\footnotetext{
${ }^{6}$ Ismail Muhammad Syah, Filsafat Hukum Islam (Jakarta: Bumi Aksara, 1991), 113115.

${ }^{7}$ al-Qur'ân, 5: 48.

8 al-Qur'ân, 2: 21. Kalimat u'budû ditemukan dalam al-Qur'ân dengan bentuk plural sebanyak dua puluh satu kali dengan rincian; 1) diawali dengan huruf wâwu sebanyak tiga kali, 2) diawali dengan fâ' sekali, dan 3) dan yang lain-lain (diawali kata sambung lainnya atau tidak) sebanyak tujuh belas kali. Lihat Muhammad Fu'âd 'Abd al-Bâqî, al-Mu'jam al-Mufahras li Alfâz al-Qur'ân al-Karîm (Beirut: Dâr al-Fikr, 1981), 442.
} 
makân). Oleh karenanya, universalitas ini dibutuhkan pada konteks fiqh bidang mu'amalah karena cakupannya yang sangat luas dan dituntut untuk selalu fleksibel.

Dewasa ini banyak persoalan-persoalan aktual menyangkut fiqh mu'âmalah baik dalam bidang politik, sosial, budaya, ekonomi, dan sebagainya yang belum dipahami oleh sebagian besar umat Islam tentang bagaimana status hukum dan solusinya, apakah persoalan itu masuk dalam kategori khilâfîyah atau tidak. Semua persoalan ini mesti diselesaikan melalui produksi fiqh yang lebih akomodatif.

Kelangkaan komunikasi fiqh kontemporer dan penghayatan sharî‘ah serta wacana ijtihad aktual yang baik dan akomodatif sebenarnya telah lama menjadi keprihatinan banyak pihak untuk menghadapi begitu banyak problematika kekinian. Sementara di pihak lain tidak mudah mendapatkan jawaban fiqh yang memuaskan atau minimal memperoleh pencerahan wawasan sharî‘ah. Hal itu dikarenakan jumlah teks-teks normatif, baik al-Qur'ân dan Sunnah, yang sangat terbatas sedangkan problematika kontemporer yang membutuhkan solusi terus-menerus bermunculan.

Bagi Jasser Auda, walaupun al-Qur'ân dan Sunnah Nabi dianggap sebagai sumber rujukan yang bersifat final, tetapi ia terbuka untuk dipahami dan ditafsirkan. Sebagai teks rujukan, keduanya telah menjadi pedoman hidup yang memiliki visi keadilan, hikmah dan kerahmatan dalam segenap situasi dan kondisi. Inilah pengertian sharî‘ah Islam dalam level pertama. Sedangkan pada level fiqh, sharî‘'ah Islam harus dipahami sebagai usaha untuk "membumikan" tujuan yang diinginkan oleh Pembuat sharîah (shâri'). Usaha ini dilakukan melalui pemikiran mendalam atau apa yang biasa disebut dengan ijtihad. Melalui ijtihad, al-Qur'ân dan Sunnah dijabarkan menjadi aturan hukum sesuai dengan situasi lingkungan yang melingkupi seorang mujtahid. Sementara pada level fatwa, sharî‘ $a h$ hanya dapat diakui sejauh mencerminkan tujuan sharî́ah itu sendiri. Sharî'ah dalam pengertian level yang terakhir ini sangat terkait dengan perwujudan dari tujuan sharî‘ah, bukan berorientasi kepada ideologi atau mazhab tertentu.

Dengan pemahaman seperti itu, maka sharî‘ah Islam adalah wahyu (al-Qur'ân dan Sunnah) yang sempurna, sedangkan kesempurnaan sharî́ah bergantung pada upayanya yang selalu berkesinambungan

${ }^{9}$ Jasser Auda, Maqasid al-Shariah as Philosophy of Islamic Law: a Systems Approach (USA dan London: The International Institute of Islamic Thought (IIIT), 2007), xxi -xxii. 
untuk menyesuaikan diri dengan kondisi masyarakat dan mengarahkan manusia pada esensi kemanusiaan dan semangat kehidupan. Di sini, sharî́ah sebagai wahyu harus dibedakan dengan hasil pemikiran tentang sharî́ah atau interpretasi terhadap wahyu. Sharî́ah bukanlah segala hukum agama, aturan ibadah, legislasi hukum, segala pendapat para ahli fiqh, mufassir, pandangan para komentator dan ajaran tokoh agama.

Pencerahan wawasan sharî́ah dapat dilakukan dengan memberikan informasi, pengetahuan serta pemahaman komprehensif dan relevan dengan masalah kontemporer sehingga mendapatkan masukan baru yang implikasinya lebih luas. Hal ini sebagaimana yang dilakukan oleh Nabi ketika ditanya tentang hukum air laut, apakah boleh dipakai untuk wudu? Nabi memberikan fatwa bahwa air laut itu suci dan halal bangkai binatangnya. ${ }^{10}$ Oleh karena itu dalam kajian fiqh diperlukan format fleksibel yang dapat memberikan wawasan jawaban sesuai prinsip maqâsid al-sharî'ah, yaitu untuk menebar kemaslahatan dan menekan terjadinya kerusakan dan kesempitan. ${ }^{11}$

\section{Prinsip Egaliter dalam Mu'âmalah}

Secara jelas al-Qur'ân menegasikan penggunaan hukum Jahiliah yang dinilai sarat dengan upaya pemihakan terhadap kelompok tertentu yang berkuasa di dalam masyarakat. Selanjutnya ditegaskan bahwa hukum Islam merupakan satu-satunya aturan yang harus dipegangi oleh manusia, karena berasal dari Allah yang memuat prinsip keadilan dan kesetaraan sosial. ${ }^{12}$

Pada periode awal Islam, Nabi Muhammad menyebarkan agama Islam secara universal kepada seluruh manusia, di bawah bimbingan wahyu. Dari rincian ajaran yang dibawa oleh Nabi pada periode awal

10 Imâm al-Turmûdhî, al-Jâmi al-Saḥ̂h, Vol. 1 (Beirut: Dâr al-Kutub al-'Ilmîyah, t.th.), 101. Lihat juga Imâm al-Nasâ'î, Sunan al-Nasâ'û, Vol. 1 (Beirut: Dâr al-Kutub al-'Ilmîyah, t.th.), 176; Ibn Mâjah, Sunan Ibn Mâjah, Vol. 1 (Beirut: Dâr al-Kutub al'Ilmîyah, t.th.), 136; Imâm al-Dârimî, Sunan al-Dârimî, Vol. 1 (Beirut: Dâr al-Kutub al-'Ilmîyah, 1996), 126.

${ }_{11}$ Menurut Jasser Auda, dengan mengutip pendapat Ibn al-Qayyim, bahwa sharî́ah pada dasarnya adalah prinsip yang berpijak pada hikmah dan kemaslahatan umat manusia. Hikmah dan kemaslahan itu harus terwujud di tengah kehidupan mereka. Sharî‘ah merupakan keadilan, rahmat, hikmah dan kemaslahatan. Maka, setiap masalah atau hal yang keluar dari keadilan, tidak dapat menghadirkan kerahmatan dan tidak mampu mewujudkan kemaslahatan, bukanlah sharî́ah meskipun didalamnya melibatkan pentakwilan. Lihat Auda, Maqasid al-Shariah, xxi -xxii.

12 al-Qur'ân, 49: 13. 
tersebut terdapat tema pokok, yaitu kebaikan dan kekuasaan Tuhan, pengadilan Tuhan di akhirat, tugas manusia untuk bersyukur dan beribadah, dan risalah kenabian Muhammad. Inti ajaran Nabi adalah ajaran Tauhid, yaitu ajaran untuk beriman kepada Allah yang juga akan meminta pertanggungjawaban setiap makhluk atas semua perbuatannya.

Konsekuensi logis dari ajaran ini adalah adanya kewajiban untuk menyembah dan bersyukur kepada Tuhan serta kewajiban untuk menjadi egaliter dan saling menyayangi antar-sesama makhluk, terutama sesama manusia. Sementara itu, secara singkat bisa dikatakan bahwa dasar ajaran pada periode awal tersebut adalah kesalihan ukhrawi, kemuliaan etis, dan pembangunan mental.

Secara umum hukum Islam berdiri di atas prinsip-prinsip yang harus dipertahankan secara absolut dan universal. Prinsip-prinsip tersebut adalah ajaran yang qat $t_{i}$ dan menjadi tolok ukur pemahaman dan penerimaan hukum Islam secara keseluruhan. ${ }^{13}$ Prinsip-prinsip tersebut dapat diidentifikasikan menjadi prinsip kebebasan dan pertanggungjawaban individu, ${ }^{14}$ prinsip kesetaraan derajat manusia di hadapan Tuhan, ${ }^{15}$ prinsip keadilan dan persamaan di hadapan hukum, ${ }^{16}$ prinsip tidak merugikan diri sendiri dan orang lain, prinsip kritik dan kontrol sosial, ${ }^{17}$ prinsip menepati janji dan menjunjung tinggi kesepakatan, ${ }^{18}$ prinsip tolong-menolong untuk kebaikan, ${ }^{19}$ prinsip yang kuat melindungi yang lemah, ${ }^{20}$ prinsip musyawarah dalam urusan bersama, ${ }^{21}$ prinsip kesetaraan suami-istri dalam keluarga, ${ }^{22}$ dan prinsip saling memberlakukan dengan baik antara suami dan istri. ${ }^{23}$

Berkenaan dengan egalitarianisme dalam Islam, QS. al-Hujurât [49]: 13 menegaskan bahwa orang yang paling mulia di hadapan Allah

13 Masdar F. Mas'udi, Islam dan Hak-hak Reproduksi Perempuan: Dialog Fiqh Pemberdayaan (Bandung: Mizan, 1997), 29.

14 al-Qur'ân, 99: 7-8.

15 al-Qur'ân, 49: 13.

16 al-Qur'ân, 5: 8.

17 al-Qur'ân, 103: 1-3.

18 al-Qur'ân, 17: 34.

19 al-Qur'ân, 5: 2.

20 al-Qur'ân, 4: 75.

21 al-Qur'ân, 26: 38.

22 al-Qur'ân, 2: 187.

23 al-Qur'ân, 4: 19. 
adalah orang yang paling betakwa, bukan orang yang paling kaya, paling pandai atau paling berkuasa, baik itu laki-laki atau perempuan dan berasal dari suku bangsa apa pun. Disebutkan di permulaan ayat tersebut bahwa manusia itu tercipta dari asal yang sama, yaitu dari seorang laki-laki dan seorang perempuan yang akhirnya tersebar ke berbagai kelompok dan suku bangsa.

Ditegaskan pula bahwa antar-manusia perlu mengadakan komunikasi dan interaksi timbal-balik. Ayat tersebut diceritakan turun berkenaan dengan beberapa peristiwa, antara lain peristiwa yang terjadi pada waktu fatḥ Makkah. Diceritakan pula bahwa Bilâl b. Rabbah mengumandangkan seruan azan dan dinilai oleh Hârith b. Hishâm tidak sepantasnya dilakukannya mengingat ia adalah bekas budak yang berkulit hitam. Suhayl b. 'Amr kemudian merespons penilaian tersebut dengan mengatakan bahwa jika perbuatan Bilâl itu salah, tentu Allah akan mengubahnya, lalu turunlah ayat yang menegaskan hal itu. ${ }^{24}$

Contoh lain adalah hukum waris di mana pembagian harta warisan pada laki-laki dan perempuan itu dua berbanding satu sebagaimana disebutkan dalam al-Qur'ân, maka hal itu harus diinterpretasikan ulang. Menurut pemahaman yang egaliter, ayat tersebut harus dipahami dengan memperhatikan dua hal penting. Pertama, pada saat itu memberi bagian warisan kepada perempuan serta mendudukkan laki-laki dan perempuan sama-sama sebagai subjek penerima harta warisan adalah upaya mereformasi tradisi Jahiliah yang tidak menjadikan perempuan sebagai subjek penerima harta warisan. Maka, Islam sudah sedemikian maju memberi ruang bagi perempuan dengan menjadi penerima harta waris. Kedua, setting sosial ekonomi dalam kehidupan keluarga pada masa munculnya aturan hukum tersebut adalah beban nafkah keluarga ditanggung oleh laki-laki, sehingga bagian warisan laki-laki lebih besar daripada bagian perempuan, dan saat itu hal itu merupakan pembagian yang adil. ${ }^{25}$

Islam muncul pada masyarakat Jahiliah dengan membawa perubahan sosial serta melawan sistem hukum yang telah mentradisi sebelumnya. Dengan adanya perubahan yang signifikan oleh Islam terhadap hukum masyarakat Arab pra-Islam, misi Islam mendapatkan sambutan dan respons dari masyarakat, baik dari kelompok

24 Abû Ḥasan 'Alî b. Aḥmad al-Wâhịî̀, Asbâb al-Nuzûl (Kairo: Maktabat al-Da'wah, t.th.), 295.

${ }^{25}$ Mas'udi, Islam dan Hak-hak Reproduksi Perempuan, 52. 
masyarakat yang menghendaki perubahan maupun dari kelompok masyarakat penentang yang menjadi penopang hukum Jahiliah yang telah ada.

Para penerima ajaran Islam awal, sebagaimana yang diidentifikasikan oleh Albert Hauroni, terdiri dari beberapa pemuda (dalam jumlah yang relatif kecil) dari keluarga Quraysh yang berpengaruh, beberapa orang (dalam jumlah yang relatif besar) anggota keluarga-keluarga yang kecil dan lemah, orang-orang yang termasuk anggota suku-suku yang di bawah perlindungan suku Quraysh dan beberapa pekerja kasar serta beberapa orang budak. Orang-orang Jahiliah yang menyambut baik ajaran Islam, seperti yang dikatakan oleh Ira M. Lapidus adalah orang-orang yang sangat tidak puas dengan kondisi moral dan kondisi sosial yang ada.

Pada proses berdakwahnya, Nabi Muhammad selalu memberikan perlakuan yang egeliter kepada para pengikut Islam tanpa membedabedakan asal-usul, status sosial, dan jenis kelaminnya. Sebelum Nabi Muhammad merombak tradisi hukum Jahiliah, proses dakwah Nabi diawali dengan persoalan keimanan dan ritual keagamaan secara rahasia, hampir-hampir tidak ada satu sikap resisten dari masyarakat Jahiliah. Namun setelah Nabi Muhammad secara terang-terangan melakukan indhâr kapada masyarakat Jahiliah, Islam memperolah perlawanan massif dari kelompok bangsawan yang kaya dan berkuasa pada masa Jahiliah, yaitu kelompok Quraysh yang sebenarnya merupakan suku Nabi Muhammad sendiri.

Pertikaian antara Nabi Muhammad (Islam) dengan kaum Quraysh Jahiliah terkait erat dengan dua aspek, yaitu keagamaan dan sosial. Aspek keagamaan bermuara pada kepercayaan tentang Allah dengan konsekuensi meninggalkan tradisi sesembahan masing-masing kabilah. Ditambah lagi dengan kepercayaan tentang alam akhirat yang menjadi tempat pertanggungjawaban perbuatan manusia yang belum pernah didengar oleh orang Quraysh sebelumnya. Tenyata aspek keagamaan yang dianut oleh suku-suku Jahiliah ini sekaligus menjadi sebuah ikatan sosial yang mempersatukan anggota dari masing-masing suku. Sehingga menganut ajaran Islam berarti dianggap keluar dari ikatan kesukuan yang telah ada dan mengubah tatanan kekuasaan pada masyarakat Jahiliah.

Tampaknya penolakan Quraysh terhadap Islam dan counter dari Nabi Muhammad terhadap penolakan tersebut berkaitan erat dengan perubahan hukum yang mempengaruhi pranata sosial dan pola 
kepemimpinan masyarakat. Dari struktur sosial dan kepemimpinan yang bernuansa pemihakan kepada kelompok kaya, bangsawan dan penguasa, menuju ke struktur sosial dan kepemimpinan yang bernuansa egaliter dan pemihakan kepada kelompok mustad'afin. Struktur sosial yang hendak dikembangkan Nabi Muhammad tersebut belakangan dirumuskan dalam konsep fiqh mu'amalah untuk mengatur pranata sosial secara berkeadilan dan memperhatikan asas persamaan.

\section{Peran Fiqh Ekonomi dalam Mengatasi Problem Sosial}

Fakta sejarah menunjukkan bahwa fiqh bidang mu'amalah atau hukum ekonomi sharî́ah sangat diperlukan dan mesti mendapatkan perhatian yang serius oleh semua pihak, lebih-lebih yang berpautan dengan persoalan-persoalan kontemporer saat ini. Dasar fiqh mu'âmalah sesungguhnya telah dirumuskan oleh para faqîh dalam kitabkitab fiqh klasik. Tentu saja dasar-dasar tersebut perlu diaktualisasikan sesuai perkembangan realitas. Artinya, bagaimana dokumen fiqh yang telah dirumuskan tersebut bisa diaplikasikan pada tatanan kegiatan bisnis yang benar-benar bermanfaat bagi kehidupan sehari-hari secara realistis.

Islam selalu menganjurkan umatnya untuk selalu berusaha dan bekerja untuk dapat memenuhi kebutuhan hidup dan terhindar dari berbagai problem sosial yang tidak bersandar pada kemaslahatan dan keadilan. Kebodohan dan kemiskinan, misalnya, merupakan penyakit sosial yang dimusuhi oleh Islam. Lantaran itulah ayat al-Qur'ân pertama kali yang diturunkan berisi seruan "membaca" 26 supaya manusia terhindar dari kebodohan. Sebab, penyakit kebodohan seperti ini dapat menyebabkan orang sengsara dan miskin lantaran tidak memiliki kompetensi yang disyaratkan untuk mengarungi kehidupan secara wajar dan terhormat. Kemiskinan pada umumnya akrab dengan kenestapaan, baik berupa munculnya penyakit-penyakit atau problem-problem kesehatan yang lain sebagai akibat terbatasnya kemampuan untuk bisa hidup secara wajar. Dalam kaitan ini

\footnotetext{
26 al-Qur'ân, 96: 1-5. Menurut al-Ṭabarî, iqra' yang pertama adalah perintah untuk Nabi Muhammad, sedangkan iqra' yang kedua adalah membaca untuk melakukan tablìgh. Lihat Abû Ja'far Muhammad b. Jarîr al-Ṭabarî, Jâmi' al-Bayân 'an al-Ta'mîl Âyât al-Qur'ân, Vol. 30 (Beirut: Dâr al-Fikr, t.th.), 319.
} 
Rasulullah pernah memperingatkan kita bahwa kondisi kefakiran sangat rentan untuk menjerumuskan seseorang kepada kekafiran. ${ }^{27}$

Islam telah memberikan perhatiannya sejak lima belas abad yang lalu terhadap orang-orang yang secara sosio-ekonomi tidak beruntung (orang-orang miskin). ${ }^{28}$ Islam sangat peduli terhadap nasib orangorang yang terpinggirkan (marginalized) akibat adanya penyakitpenyakit sosial seperti kemiskinan, kebodohan, dan lainnya.

Cukup banyak ayat-ayat al-Qur'ân yang memberikan porsi perhatian terhadap kaum tertindas seperti tercermin dalam konsep distribusi kekayaan. ${ }^{29}$ Sikap kepedulian dan keberpihakan Islam pada pemberdayaan ekonomi dapat tercermin dalam beberapa ayat alQur'ân baik dalam bentuk ibadah sosial seperti kewajiban membayar zakat, atau dalam bentuk menstimulir (memberi dorongan dan semangat) umat Islam untuk bekerja memenuhi kebutuhan diri dan keluarganya. Dalam Islam bekerja dipandang sebagai bagian dari jihâd fi sabîl Allâh. Sebaliknya, orang yang malas bekerja dan suka memintaminta sangat dikecamnya. Al-Qur'ân menyuruh manusia untuk secara sungguh-sungguh mencari rezeki untuk dapat memenuhi kebutuhan hidupnya sehari-hari. ${ }^{30}$

Dalam kehidupan sosial yang semakin kompleks dan dinamis kerap terjadi perubahan nilai-nilai kehidupan. Hal ini akan selalu berimbas pada problem perubahan tatanan baru dalam kehidupan

27 Jalâl al-Dîn 'Abd Raḥmân b. Abî Bakr al-Suyûtî, Sharh al-Jâmi' al-Ṣaghîr, Vol. 2 (Beirut: Dâr al-Fikr, t.th.), 266. Lihat juga Toto Tasmara, Membudayakan Etos Kerja Islami (Jakarta: Gema Insani, 2002), 15.

${ }^{28}$ Dalam surah al-Isrâ' ayat 26 Allah berfirman yang artinya: Dan berikanlah kepada keluarga-keluarga yang dekat akan haknya, kepada orang miskin dan orang yang dalam perjalanan. Dan tunaikanlah haknya di hari memetik hasilnya (dengan dikeluarkan zakatnya) dan janganlah kamu berlebih-lebihan. Lihat al-Qur'ân, 17: 26. Dalam surah al-Dhâriyât ayat 19 Allah Juga berfirman yang artinya: Dan pada hartaharta mereka ada hak untuk orang-orang miskin yang tidak mendapat bagian (orangorang miskin yang tidak meminta-minta. Lihat al-Qur'ân, 51: 19. Lihat juga Yusuf Qardhawi, Norma dan Etika Ekonomi Islam, terj. Zainal Arifin dan Dahlia Husin (Jakarta: Gema Insani Press, 1997), 58.

29 Seperti tercermin dalam konsep distribusi zakat pada surah Tawbah ayat 60 dan konsep distribusi harta rampasan pada surah al-Anfâl ayat 41. Lihat al-Qur'ân, 9: 60; al-Qur'ân, 8: 41.

${ }^{30}$ Menurut Umar Chapra, pemenuhan kebutuhan ini akan membawa generasi dalam kedamaian, kenyamanan, sehat, efisien serta mampu memberikan kontribusi secara baik bagi kelanggengan kebahagiaan hidup. Lihat Umar Chapra, Islam dan Tantangan Ekonomi (Jakarta: Gema Insani, 2000), 7. 
berbangsa dan bernegara dari berbagai aspek, baik sosial, ekonomi, pendidikan, hukum, budaya, politik, dan sebagainya. Transformasi seperti ini disadari atau tidak, merupakan persoalan lama sejak abadabad awal Islam yang kemunculannya bisa disebut bersamaan dengan lahirnya tokoh-tokoh Islam terkemuka, misalnya para imam mazhab. Namun demikian, dalam kasus fiqh, ia akan selalu up to date dan bergerak dinamis hingga saat ini dan masa-masa mendatang jika dikaji dan diteliti dengan menggunakan perspektif metodologis-sistematis dalam kerangka usûl al-fiqh-nya.

Pendekatan ini akan menemukan momentumnya ketika kita mampu mengkorelasikan teori-teori lama ke dalam konteks kekinian dengan segmentasi penduduk yang majemuk, yakni multiagama, multiras, multikultural, dan multisuku seperti yang tercermin dalam sebuah negara Indonesia, misalnya. Sungguhpun penduduk Muslim di negeri ini tergolong mayoritas, namun secara formal Indonesia tidak pernah mendeklarasikan sebagai negara Islam. Implementasi teoriteori fiqh klasik ke dalam konteks kehidupan modern yang multikultural dapat menghadirkan paradigma baru sebagai hasil olah pikir dalam suatu proses kreatif. Sebab, jika al-Qur'ân memberikan aturan-aturan yang bersifat global dan Sunnah menunjukkan responsnya secara faktual-lokal dalam suatu konteks masyarakat, maka dalam perkembangan kemudian, konsep fiqh mu'âmalah dalam kitab klasik dapat berperan memberikan solusi bagi kehidupan umat dengan tetap berpedoman kepada kedua sumber asasinya, yaitu al-Qur'ân dan Sunnah. ${ }^{31}$

Kemampuan improvisasi akal manusia untuk merumuskan hukum memang telah diberikan pengakuannya oleh al-Qur'ân maupun Sunnah dalam rangka menemukan penyelesaian dalam kajian hukum Islam meliputi berbagai metode, antara lain: ijmâ' (konsensus), qiyâs (deduksi analogis), istihsân (penganggapan baik), istislăh (mașlahah mursalab), istiş̣âb (pemberlakuan hukum asal), 'urf (adat kebiasaan), dan lain-lain.

Penggunaan metode-metode tersebut sangat bervariasi, bahkan kadang-kadang saling bertentangan, sebagaian ulama menggunakan metode tertentu sementara yang lain menolaknya. Meskipun demikian, sebagai suatu upaya mengaktualisir kehendak Allah yang diyakini memang tidak mudah dilakukan, semua metode ijtihad

31 Setiawan, Fiqh Aktual: Jawaban Tuntas Masalab Kontemporer (Jakarta: Gema Insani, 2003), vii-ix. 
tersebut memiliki kedudukan yang sama, yaitu sama-sama mempunyai kemungkinan untuk benar, di samping tentu saja ada kemungkinan untuk salah.

Peranan akal juga dibutuhkan dalam menyikapi berbagai dinamika kehidupan masyarakat yang berkaitan dengan aktivitas bisnis, misalnya bagaimana merumuskan mekanisme perdagangan dengan pemanfaatan sarana komunikasi agar terhindar dari perlakuan gharar (tipu daya), bagaimana merumuskan formulanya yang efektif dan sebagainya. Dalam kaitannya dengan upaya mendeskripsikan dan mengeksplorasi format atau konsep-konsep lama fiqh mu'amalah dalam kitab klasik, maka akan menjadi menarik jika kita juga mengamati proses, praktik dan perilaku bisnis dalam konteks sekarang yang serba global.

\section{Kondisi Indonesia Sekarang: Sebuah Refleksi}

Keragaman agama, etnik, dan golongan tidak memaksakan Indonesia harus merevisi sistem hukum Negara Kesatuan Republik Indonesia (NKRI), apalagi merubahnya. Bahkan di era reformasi ini sistem NKRI lebih dikukuhkan kembali dengan merevisi dan menyempurnakan sejumlah peraturan dan perundang-undangan baik di bidang politik, ketatanegaraan, sosial, dan ekonomi. Penyempurnaan ini tidak lain mencerminkan bahwa Indonesia merupakan salah satu negara bangsa di dunia ini yang tengah berikhtiar mewujudkan sistem demokrasi secara lebih paripurna. Sentralisasi kekuasaan yang menguat pada rezim Orde Baru direvisi dengan membangun otonomi daerah agar menjadi lebih kuat, mapan dan mandiri. Seperti pemilihan kepala daerah dilakukan secara langsung oleh rakyat. Tentu saja perangkat peraturan perundangundangan baru ini perlu diimbangi dengan pembangunan dan kesiapan mental-spritual rakyat yang menjalankannya. Diakui atau tidak, dalam suasana yang masih euforia ini sering terjadi penyimpangan demokrasi. Diharapkan suasana transisi dan euforia seperti ini tidak berlangsung lama karena jika tidak, maka Indonesia dinilai gagal mengembangkan negara rakyat dengan basis rakyat multikultural dan sistem demokrasi yang hendak ditegakkan.

Contoh lain, krisis ekonomi yang berkepanjangan tejadi di Indonesia ini tidak terlepas dari pola sistem dan strategi kebijakan ekonomi yang dibangun oleh Orde Baru, karena di balik hasil-hasil spektakuler seperti pembangunan ekonomi selama tiga dasawarsa ini ternyata menyisakan banyak permasalahan dan kesenjangan di hampir 
segala bidang misalnya sosial, ekonomi, dan politik. Namun demikian terlepas dari siapa yang harus bertanggung jawab atas terjadinya krisis dan kesenjangan ini, tapi yang pasti pelaksanaan proses agenda reformasi ekonomi mesti harus segera dilakukan. Kebijakan ekonomi di masa Orde Baru yang hanya mengedepankan tingkat pertumbuhan dan stabilitas daripada pemerataan yang berpihak pada pemerataan ekonomi kerakyatan ternyata telah melahirkan satu bentuk kesenjangan yang serius di berbagai sektor kehidupan karena ekonominya dibangun di atas prinsip kebebasan tanpa pertanggungjawaban. Tidak ada prinsip kesetaraan derajat, keadilan, dan persamaan manusia di hadapan hukum, tidak ada kritik dan kontrol sosial, tidak ada prinsip menepati janji dan menjunjung tinggi kesepakatan, dan tidak ada prinsip tolong-menolong untuk kebaikan. Sebaliknya, yang kuat tidak melindungi yang lemah, asas musyawarah untuk mufakat dihindari, dan bahkan prinsip saling memberlakukan dengan ma'rûf antarsesama juga jauh dari harapan. Proses pembangunan ini telah membawa bias dan hanya menguntungkan kelompok tertentu.

Akumulasi dari berbagai permasalahan dan kesenjangan yang ada ialah keterpurukan ekonomi Indonesia dalam menghadapi krisis. Lemahnya fundamen perekonomian nasional dikarenakan minimnya kreativitas ekonomi rakyat. Ketidakpercayaan rakyat terhadap kekuatan ekonominya memberikan inspirasi tentang perlunya memikirkan kembali konsep pembangunan ekonomi yang telah ada.

Konsep sistem ekonomi Islam adalah sebuah alternatif pemecahan dari permasalahan ekonomi yang melanda bangsa kita. Sebuah konsep sistem ekonomi yamg menawarkan prinsip-prinsip egalitarian, keterbukaan, keadilan, demokrasi, dan keseimbangan yang berdasarkan pada hubungan Tuhan, manusia, dan alam dalam menjawab problematika ekonomi umat.

Penyempurna peraturan dan perundang-undangan dalam bidang ekonomi juga tidak luput dari perhatian oleh semua pihak, sehingga nantinya diharapkan terwujud sistem ekonomi yang benar-benar berpihak pada pemberdayaan ekonomi lemah.

Untuk konteks negara kita (dalam perjalanan sejarahnya), bahwa konsep-konsep fiqh mu'âmalah telah mulai dirintis dengan dikeluarkan Undang-Undang No. 10 Tahun 1998 tentang perubahan atas UU No. 
7 Tahun 1992.32 Dengan lahirnya UU ini, peluang beroperasinya bisnis berbasis sharî‘ah semakin jelas seperti dapat dilihat pada pasalpasalnya. Isi ketentuan dalam pasal-pasal UU ini secara eksplisit memberi peluang beroperasinya lembaga keuangan Islam di Indonesia. Peluang ini secara lebih rinci dijabarkan dalam surat keputusan Direksi Bank Indonesia No. 32/34/KEP/DIR tanggal 12 Mei 1999 tentang Bank Umum berdasarkan sharî‘ah dan No. 32/36/KEP/DIR tanggal 12 Mei 1999 tantang Bank Perkreditan Rakyat berdasarkan prinsip sharî‘ah. Peluang secara yuridis tersebut semakin jelas jangkauannya dengan dibuka kesempatan bagi bankbank konvensional, khususnya bank umum untuk melakukan kegiatan berdasarkan prinsip sharî́ah dengan membuka cabang khusus untuk kegiatan tersebut. Praktik ini secara empiris telah membuktikan kekokohan, kekuatan dan kemandiriannya kepada dunia perbankan umumnya ketika semua lembaga keuangan dilanda krisis moneter yang berkepanjangan pada tahun 90 -an lalu.

Mengutip pernyataan Warkum ${ }^{34}$ bahwa dengan dikeluarkannya Peraturan Pemerintah Republik Indonesia tersebut, maka akan memberikan peluang untuk bertumbuh-kembangnya lembagalembaga keuangan berbasis sharî‘ah. Itu artinya bahwa prinsip yang ditanamkan oleh sharî‘ah dapat hidup dan diterima sepanjang waktu dan tempat (sâliḥ li kull zamân wa makân). ${ }^{35}$

\section{Penutup}

Konsep atau konstruksi ekonomi Islam harus dibangun dengan selalu mengedepankan nilai-nilai yang diwariskan oleh agama, baik yang digali dari sumber al-Qur'ân maupun dari al-Sunnah. Sistem ekonomi Islam berdiri di atas prinsip-prinsip egalitarian yang mengedepankan asas persamaan dan harus dipertahankan secara absolut dan universal. Prinsip-prinsip seperti ini merupakan segmen

32 Undang-Undang Nomor 7 Tahun 1992 tentang Pokok-pokok Perbankan (Surabaya: Tinta Mas Pustaka, 1993).

33 Sukses dan keberhasilannya dalam perjalanan sejarah perbankan di Indonesia, bank yang berprinsip sharî‘ah ini diikuti oleh BPR Islam yang lain hingga mencapai lebih dari 50 buah. Lihat Warkum, Asas-asas Perbankan Islam dan Lembaga-lembaga Terkait (Jakarta: PT. Raja Grafindo Persada, 2002), 3.

34 Ibid., 5-16. Bahkan menurut Adiwarman Karim bisnis ala sharî‘ah tersebut sudah mulai dirintis sejak tahun 70-an dengan diperkenalkannya sistem ekonomi Islam. Lihat Karim Adiwarman, Bank Islam: Analisis Fiqh dan Kenangan (Jakarta: PT. Raja Grafindo Persada, 2004), xvi.

35 Ibid., vii. 
ajaran yang qat $i \hat{i}$ dan menjadi tolok ukur pemahaman dan penerimaan hukum Islam secara keseluruhan. Prinsip-prinsip tersebut adalah prinsip tauhid, keimanan, akhlak, moral atau etika, keseimbangan antara orientasi duniawi dan ukhrawi, keadilan dan kemanusiaan.

Atas prinsip egalitarian ini, maka orang yang paling mulia dan paling berkualitas di hadapan Tuhan adalah mereka yang paling tinggi kadar takwanya, bukan orang yang paling kaya, paling pandai atau paling berkuasa. Dalam pergumulan sosialnya, manusia sebagai makhluk Tuhan mengadakan komunikasi dan interaksi timbal balik untuk saling melengkapi kebutuhan hidupnya. Untuk itu, fiqh mu'amalah yang dapat mewadahi persoalan-persoalan bisnis yang lebih konkret sesuai dengan kebutuhan masyarakat adalah solusinya.

Untuk menemukan pencerahan dalam wawasan fiqh mu'amalah kontemporer, maka diperlukan konsep sistematis-metodologis, yang dapat mengaktualisasikan teori-teori fiqh klasik sesuai konteks persoalan kekinian. Dengan kombinasi khazanah klasik dan persoalan kontemporer ini diharapkan sistem ekonomi Islam bisa lahir sesuai kebutuhan masyarakat sekarang.

\section{Daftar Rujukan}

Auda, Jasser. Maqasid al-Shariah as Philosophy of Islamic Law: a Systems Approach. USA dan London: The International Institute of Islamic Thought (IIIT), 2007.

Bâqî (al), Muhammad Fu'âd 'Abd. al-Mu'jam al-Mufahras li Alfầa alQur'ân al-Karîm. Beirut: Dâr al-Fikr, 1981.

Chapra, Umar. Islam dan Tantangan Ekonomi. Jakarta: Gema Insani, 2000.

Dârimî (al), Imam. Sunan al-Dârimî, Vol. 1. Beirut: Dâr al-Kutub al'Ilmîyah, 1996.

Hiijâzî, Mạ̣mûd Muhammad. Al-Tafsîr al-Wạdị̆, Vol. 1. Bairut: Dâr al-Jabal, t.th.

Karim, Adiwarman. Bank Islam: Analisis Figh dan Kenangan. Jakarta: PT. Raja Grafindo Persada, 2004.

Kathîr, Ibn. Tafsîr al-Qur'ân al-'Ažim, Vol. 4. Bairut: Dâr al-Fikr, t.th.

Mâjah, Ibn. Sunan Ibn Mâjah, Vol. 1. Beirut: Dâr al-Kutub al-'Ilmîyah, t.th.

Mas'udi, Masdar F. Islam dan Hak-hak Reproduksi Perempuan: Dialog Fiqh Pemberdayaan. Bandung: Mizan, 1997. 
Nasâ'î (al), Imâm. Sunan al-Nasâ'î, Vol. 1. Beirut: Dâr al-Kutub al'Ilmîyah, t.th.

Qardhawi, Yusuf. Norma dan Etika Ekonomi Islam, terj. Zainal Arifin dan Dahlia Husin. Jakarta: Gema Insani Press, 1997.

Setiawan. Fiqh Aktual: Jawaban Tuntas Masalah Kontemporer. Jakarta: Gema Insani, 2003.

Suyûtî (al), Jalâl al-Dîn 'Abd al-Raḥmân b. Abî Bakr. Sharḥ al-jâmi' alSaghîr, Vol. 2. Beirut: Dâr al-Fikr, t.th.

Syah, Ismail Muhammad. Filsafat Hukum Islam. Jakarta: Bumi Aksara, 1991.

Ṭabarî (al), Abû Ja'far Muhammad b. Jarîr. Jâmi' al-Bayân 'an al-Ta'wîl Ayât al-Qur'ân, Vol. 30. Beirut: Dâr al-Fikr, t.th.

Tasmara, Toto. Membudayakan Etos Kerja Islami. Jakarta: Gema Insani, 2002.

Tumûdhî (al), Imâm. al-Jâmi' al-Sahịh, Vol. 1. Beirut: Dâr al-Kutub al'Ilmîyah, t.th.

Undang-Undang Nomor 7 Tahun 1992 tentang Pokok-pokok Perbankan. Surabaya: Tinta Mas Pustaka, 1993.

Wâhịî̀ (al), Abû Ḥasan 'Alî b. Aḥmad. Asbâb al-Nuحûl. Kairo: Maktabat al-Da'wah, t.th.

Warkum. Asas-asas Perbankan Islam dan Lembaga-lembaga Terkait. Jakarta: PT. Raja Grafindo Persada, 2002. 